\title{
Mountain Glacier Chronology from Boulder Lake, New Zealand, Indicates MIS 4 and MIS 2 Ice Advances of Similar Extent
}

Authors: McCarthy, Andrew, Mackintosh, Andrew, Rieser, Uwe, and Fink, David

Source: Arctic, Antarctic, and Alpine Research, 40(4) : 695-708

Published By: Institute of Arctic and Alpine Research (INSTAAR), University of Colorado

URL: https://doi.org/10.1657/1523-0430(06-111)[MCCARTHY]2.0.CO;2

BioOne Complete (complete.BioOne.org) is a full-text database of 200 subscribed and open-access titles in the biological, ecological, and environmental sciences published by nonprofit societies, associations, museums, institutions, and presses.

Your use of this PDF, the BioOne Complete website, and all posted and associated content indicates your acceptance of BioOne's Terms of Use, available at www.bioone.org/terms-of-use.

Usage of BioOne Complete content is strictly limited to personal, educational, and non - commercial use. Commercial inquiries or rights and permissions requests should be directed to the individual publisher as copyright holder.

BioOne sees sustainable scholarly publishing as an inherently collaborative enterprise connecting authors, nonprofit publishers, academic institutions, research libraries, and research funders in the common goal of maximizing access to critical research. 


\section{Mountain Glacier Chronology from Boulder Lake, New Zealand, Indicates MIS 4 and MIS 2 lce Advances of Similar Extent}

\author{
Andrew McCarthy* \\ Andrew Mackintosh*+ \\ Uwe Rieser* and \\ David Fink $\dagger$
}

*School of Geography, Environment and Earth Sciences, Victoria University of Wellington, PO Box 600, Wellington, New Zealand

$\uparrow$ Australian Nuclear Science and Technology Organisation (ANSTO), PMB 1, Sydney, NSW 2234, Australia †Corresponding author:

andrew.mackintosh@vuw.ac.nz

\begin{abstract}
Dating of past glaciation in New Zealand allows Quaternary climatic events to be identified in areas at a great distance from northern hemisphere ice sheets and associated climatic feedbacks. Moreover, climate reconstruction in New Zealand provides insight into the amount of climate change that occurred in the Southwest Pacific where zonal circulation is an important integrator of the climate signal. Boulder Lake is a relatively low-elevation cirque in a range of moderate-relief $(\sim 1600 \mathrm{~m})$ mountains in South Island of New Zealand, and it experienced cirque and valley glaciation during the Late Quaternary. Geomorphic mapping, ${ }^{10} \mathrm{Be}$ and

${ }^{26} \mathrm{Al}$ exposure, and luminescence dating provide evidence for glacial advances during the Last Glacial Cycle, specifically during Marine Isotope Stage 4 (MIS 4) and Marine Isotope Stage 2 (MIS 2). The MIS 4 advance was fractionally larger and is dated by a former ice-marginal lacustrine deposit (minimum age) with a basal Optically Stimulated Luminescence (OSL) sediment deposition age of $64.9 \pm 10 \mathrm{ka}$. Paired ${ }^{10} \mathrm{Be}$ and ${ }^{26} \mathrm{Al}$ constrain a slightly less extensive MIS 2 glacial advance to 18.2 \pm 1.0 and $17.8 \pm 0.9 \mathrm{ka}$, coincident with the Last Glacial Maximum (LGM). Glacial equilibrium-line altitudes during both MIS 4 and MIS 2 phases were $\sim 960 \mathrm{~m}$ lower than the present. This corresponds to a cooling of $5-7^{\circ} \mathrm{C}$, taking possible precipitation variability into account. Our findings and a growing number of publications indicate that many temperate valley glaciers reacted differently to the major ice sheets during the Last Glacial Cycle, reaching their maximum extent during MIS 4 rather than during peak global ice volume during MIS 2.
\end{abstract}

DOI: 10.1657/1523-0430(06-111)[MCCARTHY]2.0.CO;2

\section{Introduction}

New Zealand, together with Tasmania and South America, are the only regions to have experienced extensive Quaternary mid-latitude glaciation in the southern hemisphere. Situated at 34 $45^{\circ} \mathrm{S}$ in the remote Southwest Pacific region, New Zealand is well positioned to record changes in the ocean-atmosphere system without complexities associated with northern hemisphere ice sheets or continental influences. Many glaciers at this latitude are presently characterized by large mass balance gradients, high flow rates, and rapid responses to climatic change (Woo and Fitzharris, 1992). They are excellent targets for glacier-climate reconstruction.

Mountain glaciation was widespread in elevated areas of the South Island during the Last Glacial Cycle (LGC) (Suggate, 1990; Williams, 1996). The extent and timing of glacial expansion during this period is well constrained in the central Southern Alps where three glacial advances of similar extent culminated at 28, 21.5, and $19 \mathrm{ka}$, with widespread deglaciation following shortly after (Suggate, 1990; Almond et al., 2001; Schaefer et al., 2006; Alloway et al., 2007). Relatively little is known about the structure of glaciation in New Zealand during Marine Isotope Stages (MIS) 3 and 4. Evidence from Fiordland and Westland indicates that earlier advances during the LGC may have been more extensive than MIS 2 ice limits (Williams, 1996; Preusser et al., 2005; Sutherland et al., 2007), a finding emerging in many mountainous regions including Tasmania (Mackintosh et al., 2006), the North American cordillera (Phillips et al., 1996) and the tropical Andes
(Smith et al., 2005). In New Zealand, further evidence is required to reveal the extent and timing of these advances.

Quantitative estimates of past terrestrial temperature and precipitation during the LGC in New Zealand are rare. Estimates of equilibrium-line depression from glaciers in the Southern Alps range from 740 to $875 \mathrm{~m}$ above sea level (a.s.l.) (Porter, 1975; Bacon et al., 2001). Calculation of MIS 2 temperature decreases from fossil beetle and pollen data range from 0 to $7^{\circ} \mathrm{C}$ (Marra et al., 2006; Shulmeister et al., 2001), and debate exists in the interpretation of speleothem data, as to whether precipitation increased or decreased during this time (Hellstrom et al., 1998; Williams et al., 2005). Reduced precipitation is supported by some vegetation reconstructions (McGlone et al., 1993). However, it has been hypothesized that enhanced westerly circulation during glacial times may have caused increased precipitation (Hellstrom et al., 1998) or steeper west-to-east moisture gradients (Salinger, 1983). A regional climate modeling study of New Zealand at the LGM has come some way to addressing these issues, showing that precipitation decreased overall by $\sim 8 \%$ and that winter and spring precipitation decreased by $\sim 25 \%$ and $\sim 17 \%$ in the northern and western South Island, respectively (Drost et al., 2007).

Little systematic glacial-climate research has been undertaken in New Zealand away from the central Southern Alps. Marginal areas are likely to advance our understanding of past climate in New Zealand according to a recent review (Alloway et al., 2007) because glaciation was restricted and less complex in these areas. 


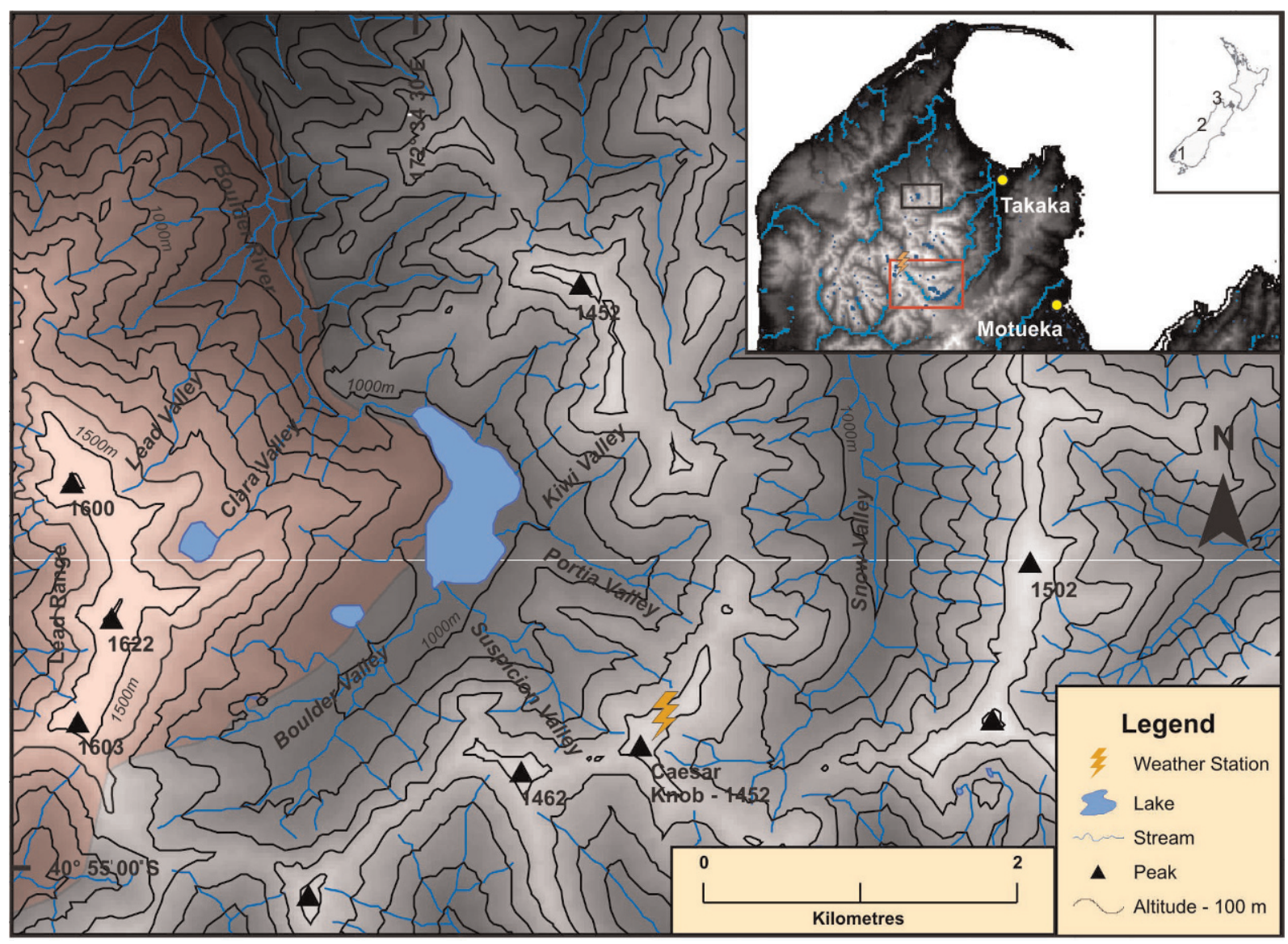

FIGURE 1. Inset map-location of Fiordland (1), Westland (2), and the study region (3). Middle map shows proximity of Cobb Valley (white box) and the Boulder-Snow Valley study area (black box). Main map-study area including major peaks, important drainage features, and weather station. Note the restriction of granite bedrock (red online) to the elevated western portion of Boulder River catchment.

This work investigates the extent, timing, and climatic drivers of glaciation in an area of marginal glaciation in New Zealand.

\section{ENVIRONMENT AND PREVIOUS WORK}

Boulder Valley and Snow Valley are situated in the Tasman Mountains, $40 \mathrm{~km}$ from the Tasman Sea and $20 \mathrm{~km}$ north of Cobb Valley, a well-known area of former glaciation (Shulmeister et al., 2005) (Fig. 1). Topography is geologically controlled whereby peaks formed in western, granite-dominated terrain exceed $1600 \mathrm{~m}$ a.s.l. while those located in metamorphic rocks further east are $\sim 200 \mathrm{~m}$ lower. Data from Cobb Valley climate station $\left(823 \mathrm{~m}\right.$ a.s.1.) indicate a mean annual temperature of $8.2^{\circ} \mathrm{C}$, with a June mean of $3.0^{\circ} \mathrm{C}$ and a February mean of $13.8^{\circ} \mathrm{C}$ (New Zealand Meteorological Service, 1978). Mean annual precipitation measured within the Boulder Lake catchment (Fig. 1) is $3100 \mathrm{~mm}$ (1990-2004), but this is a minimum estimate as the local rain gauge experiences under-catch (M. Doyle, personal communication). Annual precipitation in the Cobb Valley is approximately $5600 \mathrm{~mm}$ (New Zealand Meteorological Service, 1978), and $4500 \mathrm{~mm} \mathrm{yr}^{-1}$ is considered a "best guess" estimate for rainfall in Boulder Valley and Snow Valley. Synoptic climate information indicates that westerly airflow dominates (Salinger, 1983).

Former glaciation in the Tasman Mountains was recognized by Dobson (1872) who cited evidence for "glacial action" between Mount Arthur and Boulder Lake. Subsequent work described glacial landforms within the region (Henderson, 1923; Wellman, 1940), but modern studies that include the application of absolute dating methods were not conducted until recently. Cosmogenic exposure dating of moraines and glacially abraded bedrock surfaces in the Cobb Valley showed that glaciation occurred during MIS 2, with ice retreat commencing around 18-19 ka and finishing by $14 \mathrm{ka}$ (Shulmeister et al., 2005).

\section{Methods}

We focused on the geographic distribution of moraines and trimlines and their relationship to non-glacial and/or periglacial features such as deeply weathered bedrock and blockfields to delineate former ice-covered regions during the last period of glacial expansion (Stone et al., 1998; Ballantyne, 2002) (Fig. 2). Mapping was carried out using 1:15,000 topographic base maps, enlarged from the 1:50,000 New Zealand map series. Aerial and ground photo analysis verified and extended field mapping. All data were compiled within a GIS.

The timing of former glaciation was constrained by cosmogenic exposure and Optically Stimulated Luminescence (OSL) dating. Two moraine boulders were sampled for ${ }^{10} \mathrm{Be}$ and ${ }^{26} \mathrm{Al}$ cosmogenic dating (Figs. 3f and 3g). Large rounded granitic clasts were sampled as they demonstrate glacial transport, minimize the likelihood of inheritance, and are less likely to have moved since deposition.

In situ cosmogenic ${ }^{10} \mathrm{Be}$ and ${ }^{26} \mathrm{Al}$ concentrations were measured in these two samples at the ANSTO ANTARES Accelerator Mass Spectrometry (AMS) Facility, Australia (Fink et al., 2004) following sample preparation at ANSTO (Child et al., 


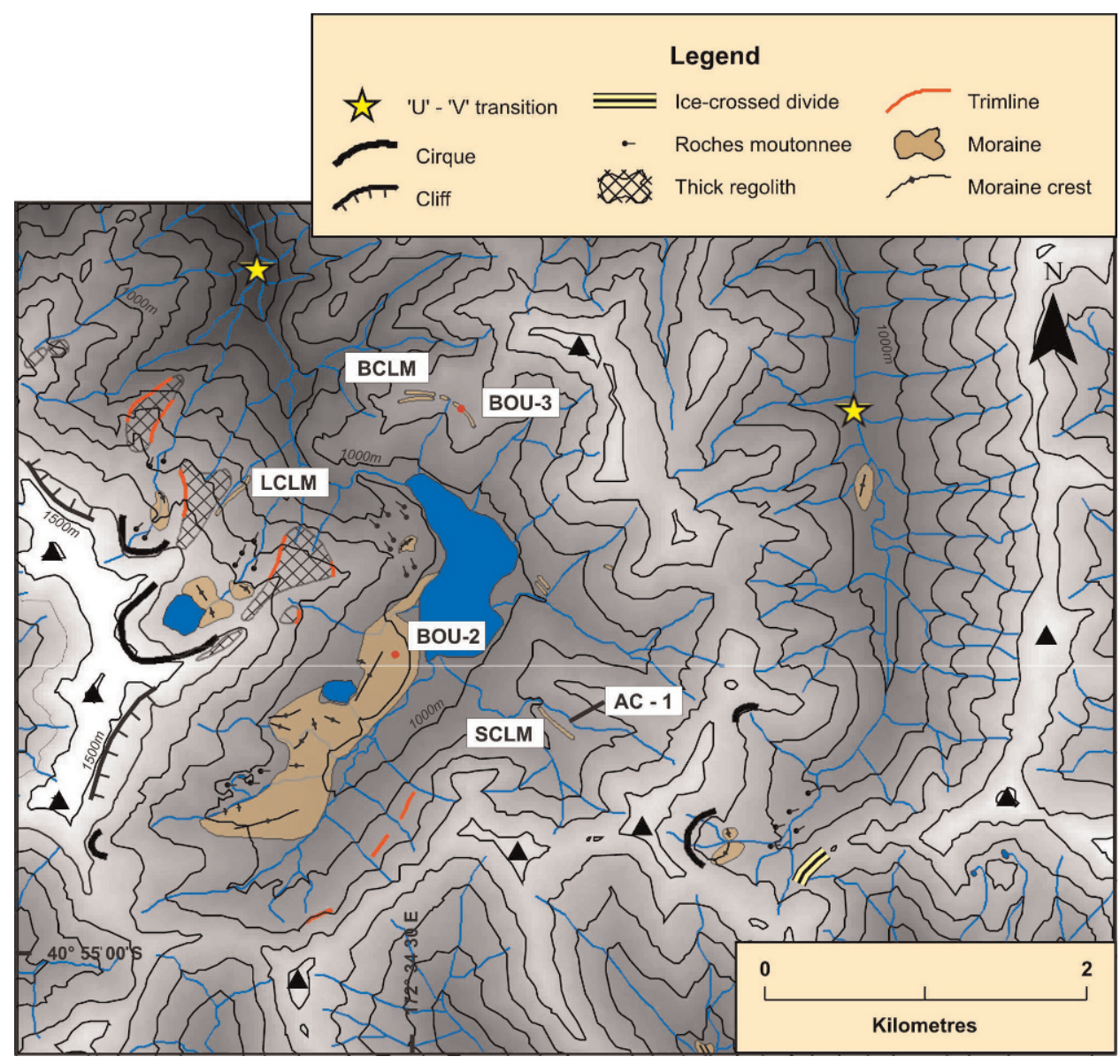

FIGURE 2. Geomorphological map of Boulder Valley and Snow Valley. Note the location of cosmogenic exposure samples BOU-2 and BOU-3 (white dots) and outcrop AC-1. BCLM-Beak Creek Lateral Moraine, LCLM-Lake Clara Lateral Moraine, SCLMSuspicion Creek Lateral Moraine.
2000). Sample description and AMS isotopic ratios are given in Table 1 and exposure age calculations are presented in Table 2. AMS isotopic ratios were determined after chemistry blank subtraction and normalization to AMS standards used by the ANTARES AMS Facility. Independent repeat AMS measurements were combined as weighted means, taking the larger of the total statistical error or mean standard error as the final analytical AMS ratio error. Absolute ratios for ${ }^{26} \mathrm{Al} / \mathrm{Al}$ were obtained by normalization to the PRIME-Z93-0221 ${ }^{26} \mathrm{Al} / \mathrm{Al}$ standard with a nominal value of $16,800 \times 10^{-15}$ (Vogt et al., 1994) and to the NIST-4325 ${ }^{10} \mathrm{Be} / \mathrm{Be}$ standard with a modified value of $30,200 \times$ $10^{-15}$ determined by Middleton et al. (1993). This result is in contrast to the certified ${ }^{10} \mathrm{Be} / \mathrm{Be}$ ratio of $26,800 \times 10^{-15}$ quoted on the NIST certificate (SRM-4325 Certificate, issued July 1990 by National Institute of Standards and Technology, 100 Bureau Drive, Stop 1070, Gaithersburg, Maryland 20899-1070, U.S.A.; $<$ http://www.nist.gov $>$ ). Recent reassessment of the NIST standard reference material SRM-4325 for ${ }^{10} \mathrm{Be}$ (Nishiizumi et al., 2007) appears to confirm the accuracy of the certified NIST quoted ratio, although confirmation awaits for an independent and direct remeasurement of the ${ }^{10} \mathrm{Be}$ half-life (see Fink and Smith, 2007, for details). Recalculation of AMS cosmogenic isotope ratio measurements presented in Table 1 to the NIST certified SRM value will reduce the ${ }^{10} \mathrm{Be}$ concentration given in Table 2 by $\sim 11 \%$ but not alter the ${ }^{10} \mathrm{Be}$ exposure ages due to a commensurate reduction in the sea-level high-latitude calibration production rate from 5.1 to 4.5 atoms $\mathrm{g}^{-1} \mathrm{yr}^{-1}$.

Chemistry blank samples were prepared from commercially purchased $1000 \mathrm{ppm} \mathrm{Be}$ and $\mathrm{Al}$ standard ICP solutions and gave ratios of $\sim 35 \times 10^{-15}$ for ${ }^{10} \mathrm{Be} / \mathrm{Be}$ and $10 \times 10^{-15}$ for ${ }^{26} \mathrm{Al} / \mathrm{Al}$. Native $\mathrm{Al}$ concentrations in the dissolved purified quartz fraction were measured by ICP-AES and the final uncertainty in ${ }^{10} \mathrm{Be}$ and ${ }^{26} \mathrm{Al}$ concentrations (atoms/gram quartz) represents quadrature addition of $1 \sigma$ errors in final AMS isotope ratio, a $1 \%$ error in quartz sample and carrier masses, and $4 \%$ for $\mathrm{Al}$ assay.

In situ cosmogenic exposure ages in Table 2 are derived from the scaling methods reported by Stone (2000) and Dunai (2000) combined with the high-latitude sea-level production rates deduced by Stone $(2000)$ of $5.1 \pm 0.3$ and $31.1 \pm 1.9$ atoms $g$ quartz ${ }^{-1} \mathrm{yr}^{-1}$ for ${ }^{10} \mathrm{Be}$ and ${ }^{26} \mathrm{Al}$, respectively. Boulder ages were calculated as weighted means of their respective individual isotope ages. Exposure age errors include a $7 \%$ error in quoted HLSL production rates, but not in scaling factors nor in attenuation length. Corrections to these scaling factors included in our calculations account for a $4 \mathrm{~cm}$ sample thickness (0.96) and an estimated horizon topographic shielding of cosmic rays of 0.98 and 0.99. Corrections for surface erosion, intermittent snow cover, and geomagnetic dipole wander recorded over the past $20 \mathrm{ka}$ were not included. Production rate corrections due to a time-varying paleogeomagnetic field based on methods presented by Dunai (2001) tend to reduce ages by at most 3-4\%.

OSL dating was carried out on silty lacustrine sediments within the section at outcrop AC-1. Sampling was done using light-tight cutting steel cylinders, which were only opened in the laboratory darkroom to avoid accidental light exposure. Sample preparation involved treatment with $\mathrm{H}_{2} \mathrm{O}_{2}$ to destroy organic material and $\mathrm{HCl}$ to remove carbonates. Iron oxide coatings were removed by a solution of sodium citrate, sodium bicarbonate, and sodium dithionate. Grain size separation in a water-filled measuring cylinder according to Stokes' Law yielded abundant material of the fraction $4-11 \mu \mathrm{m}$. This polymineral separate was deposited evenly in a thin layer on 70 aluminum discs by bringing 


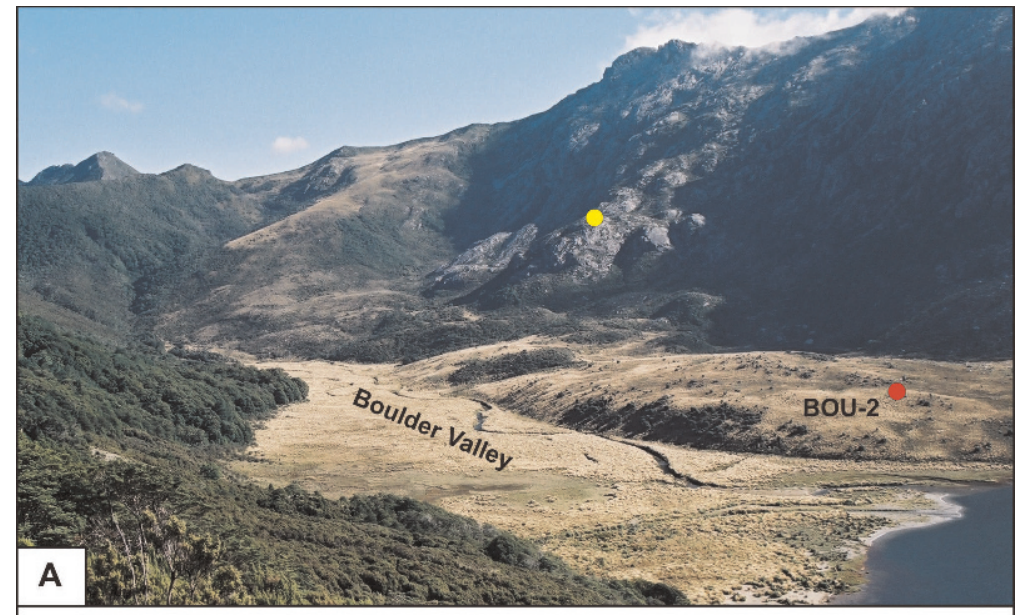

FIGURE 3. (A) "U" morphology in Boulder Valley. Cirque formation in upper Boulder Valley (center-top) occurred preferentially along the contact between metasedimentary and granite bedrock. The large area of hummocky moraine (center-right) represents the terminal region of a late stage cirque glacier. (B) Cirque development on the eastern flank of Lead Range. This region was the primary source of ice for Boulder Glacier. Image was constructed using a $25 \mathrm{~m}$ Digital Elevation Model (DEM) and aerial photo. White dots represent same point on each image. Black dots represent cosmogenic exposure sample BOU-2.

it in suspension with pure acetone and letting the acetone evaporate.

The OSL dating approach was "multiple aliquot additive dose IRSL on polymineral finegrains," similar to the technique described by Lang and Wagner (1997). "Multiple aliquot additive dose" means that, in order to avoid sensitivity changes, after normalization every disc is measured only once and then discarded. Thirty of these discs had defined laboratory radiation doses added to establish the growth curve (radiation dose versus luminescence intensity), which is needed to determine the dose the grains received in nature since deposition $\left(\mathrm{D}_{\mathrm{e}}\right.$, equivalent dose). Infrared Stimulated Luminescence (IRSL) selectively stimulates the feldspars in our polymineral sample. The Riso TL-DA15 luminescence reader was equipped with optical filters Kopp 5-58 and Schott BG39 to ensure the selective measurement of the $410 \mathrm{~nm}$ feldspar band, which is known to minimize fading effects. A separate $\alpha$-irradiated set of aliquots was used to measure the avalue.

The dose rate was obtained from a gamma spectrometry measurement using an ultra-low background Canberra BE-50 germanium detector. The 6-inch $(15.2-\mathrm{cm})$ lead and copper shielded instrument has a nominal efficiency of $50 \%$, and measures the whole energy range from 40 to $2700 \mathrm{keV}$, covering most of the $\mathrm{U}$ - and Th-chains, as well as ${ }^{40} \mathrm{~K}$. About $80 \mathrm{~g}$ of dried sample was stored for 4 weeks in an airtight "hockey-puck geometry" perspex container to achieve radioactive equilibrium of radon-daughter nuclides, and then measured. The activity concentrations of ${ }^{40} \mathrm{~K}$, ${ }^{208} \mathrm{Tl},{ }^{212} \mathrm{~Pb},{ }^{228} \mathrm{Ac},{ }^{214} \mathrm{Bi},{ }^{214} \mathrm{~Pb}$, and ${ }^{226} \mathrm{Ra}$, analyzed with Canberra's Genie2000 software, form the basis of the dose rate calculation which is using the conversion factors by Adamiec and
Aitken (1998). The cosmic dose rate calculation follows Prescott and Hutton (1994).

In addition, relative dating techniques including weathering rind analysis and moraine morphology were utilized. Landforms were distinguished by the rind thickness of between 30 and 60 surficial clasts (single lithology) on each moraine in the study area (Colman and Pierce, 1981). Widening crest width and decreasing crest-normal slope angles are common to all models of moraine degradation whereby older moraines display subdued morphology relative to younger moraines (Hallet and Putkonen, 1994; Putkonen and Swanson, 2003). Crest width, ice-proximal slope, and ice-distal slope were measured with the aid of a measuring tape and Abney level at the mid-point of each moraine (following Colman and Pierce, 1986).

The reconstruction of former ice limits and glacier surface profiles allowed Equilibrium-Line Altitude (ELA) to be calculated using either an Accumulation Area Ratio (AAR) or a Toe to Headwall Altitude Ratio (THAR), depending on former glacier size and shape. The AAR technique integrates ice-surface area into the equation, thus producing the most reliable results for complex valley glacier systems (Meierding, 1982). Planimetry errors associated with the AAR method become enhanced at small scales, making the THAR technique best suited to smaller glaciers (Porter, 1975). An AAR of 0.65 was applied to Boulder Glacier and Snow Glacier after assessing their respective area/altitude distributions (following Leonard, 1984). A THAR of 0.45 was applied to late stage cirque glaciers (following Meierding, 1982).

Valley glacier extent, and the associated ELA, depends primarily on ablation season temperature and accumulation season precipitation, although other climatic variables (cloudiness, 

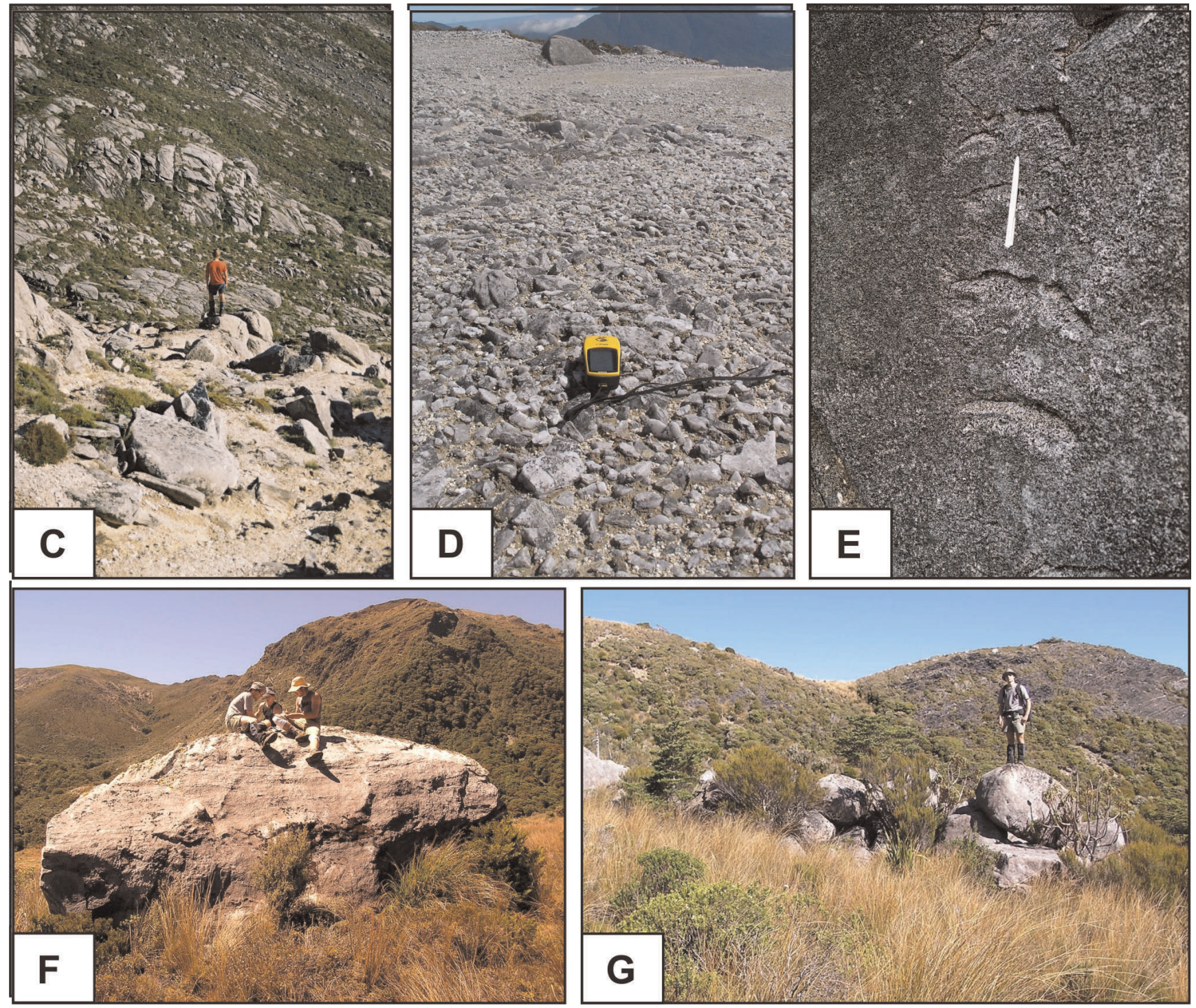

FIGURE 3. Continued. (C) Granite trimlines separate pale-yellow weathered bedrock from gray glacially abraded bedrock. (D) Weathered regions are mantled by thick accumulations of granitic regolith and localized quartz pavement development. (E) Regions below trimlines often have crescentic gouges inscribed in bedrock surfaces. (F) Boulder BOU-2 sampled for cosmogenic exposure age. (G) Boulder BOU-3 sampled for cosmogenic exposure age.

near surface wind velocity, and humidity) are also important (Ohmura et al., 1992). Divergence between reconstructed and modern ELAs should therefore reflect changes in these two dominant parameters with time. Ablation season temperature depression may be calculated by multiplying documented ELA depression by an environmental lapse rate. This approach assumes no change in precipitation occurred between glacial time and the present day (e.g., Porter, 2001). An envelope of possible temperature changes can be estimated if the relative sensitivity of glacier mass balance to temperature and precipitation change is known (e.g. Anderson and Mackintosh, 2006) and both approaches are attempted here.

TABLE 1

Average ${ }^{10} \mathrm{Be} / \mathrm{Be}$ and ${ }^{26} \mathrm{Al} / \mathrm{Al}$ AMS isotopic ratios and associated data for Boulder Lake samples.

\begin{tabular}{|c|c|c|c|c|c|c|c|}
\hline Sample name & $\begin{array}{l}{ }^{10} \mathrm{Be}^{1} \mathrm{Be}^{*} \\
\left(\times 10^{-15}\right)\end{array}$ & $\begin{array}{c}{ }^{10} \mathrm{Be} / \mathrm{Be} \text { error }{ }^{\dagger} \\
\text { (analytical) }\left(\times 10^{-15}\right)\end{array}$ & $\begin{array}{l}{ }^{26} \mathrm{Al} / \mathrm{Al}^{*} \\
\left(\times 10^{-15}\right)\end{array}$ & $\begin{array}{c}{ }^{26} \mathrm{Al} / \mathrm{Al} \text { error }^{\dagger} \\
\text { (analytical) }\left(\times 10^{-15}\right)\end{array}$ & $\begin{array}{l}\text { Be carrier mass } \\
(\mathrm{mg})\end{array}$ & $\begin{array}{c}\mathrm{Al} \text { conc } \\
(\mathrm{ppm})\end{array}$ & $\begin{array}{c}\text { Quartz mass } \\
(\mathrm{g})\end{array}$ \\
\hline BOU-2 & 436.3 & 18.1 & 2447 & 126 & 0.407 & 21.2 & 59.70 \\
\hline BOU-3 & 701.0 & 19.4 & 2715 & 192 & 0.422 & 21.5 & 85.42 \\
\hline
\end{tabular}

* Final AMS isotopic ratio determined after chemistry blank subtraction and normalization to AMS standards in use at the ANTARES AMS Facility (see text for details; Fink et al., 2007).

${ }^{\dagger}$ Independent repeat AMS measurements were combined as weighted means with the larger of the total statistical error or mean standard error. Analytical error includes in quadrature a $1-2 \%$ systematic variability in repeat measurement of AMS standards. 
TABLE 2

${ }^{10} \mathrm{Be}$ and ${ }^{26} \mathrm{Al}$ exposure ages from Boulder Lake, New Zealand.

\begin{tabular}{|c|c|c|c|c|c|c|c|c|}
\hline Sample name & $\begin{array}{c}\text { Sample elevation } \\
\text { (m a.s.1.) }\end{array}$ & $\begin{array}{l}{ }^{10} \text { Be concentration } \\
\text { (atoms/g-Q) }\left(\times 10^{3}\right)\end{array}$ & $\begin{array}{l}{ }^{26} \mathrm{Al} \text { concentration } \\
(\text { atoms } / \mathrm{g}-\mathrm{Q})^{*}\left(\times 10^{3}\right)\end{array}$ & $\begin{array}{l}\text { Scaling } \\
\text { factor }^{\dagger}\end{array}$ & $\begin{array}{l}\text { Depth and } \\
\text { Shielding } \\
\text { correction }\end{array}$ & $\begin{array}{c}{ }^{10} \mathrm{Be} \text { minimum } \\
\text { exposure } \\
\text { age }(\mathrm{ka})\end{array}$ & $\begin{array}{c}{ }^{26} \mathrm{Al} \text { minimum } \\
\text { exposure } \\
\text { age }(\mathrm{ka})\end{array}$ & $\begin{array}{c}\text { Wgted Mean } \\
\text { boulder age }{ }^{\S}(\mathrm{ka})\end{array}$ \\
\hline BOU-2 & 1010 & $198.8 \pm 9.4$ & $1156 \pm 65$ & 2.250 & 0.96 & $18.1 \pm 1.3$ & $17.4 \pm 1.4$ & $17.8 \pm 0.9$ \\
\hline BOU-3 & 1160 & $231.2 \pm 8.2$ & $1305 \pm 97$ & 2.528 & 0.96 & $18.8 \pm 1.3$ & $17.4 \pm 1.6$ & $18.2 \pm 1.0$ \\
\hline
\end{tabular}

* Cosmogenic isotope concentrations at site location $\left(41^{\circ} \mathrm{S}, 173^{\circ} \mathrm{E}\right)$.

${ }^{\dagger}$ Altitude and latitude scaling factors from Stone (2000).

${ }^{\ddagger}$ Minimum exposure ages based on ${ }^{10} \mathrm{Be}$ half-life $=1.51 \mathrm{Ma}$ and ${ }^{26} \mathrm{Al}$ half-life $=0.72 \mathrm{Ma}$. Single isotope age errors propagated from concentrations with additional errors of $7 \%$ in production rate.

${ }^{\S}$ Boulder age taken as the weighted mean age of individual isotope ${ }^{10} \mathrm{Be}$ and ${ }^{26} \mathrm{Al}$ ages. Final age error per boulder taken as the standard error in the mean.

\section{Results}

\section{EROSIONAL LANDFORMS AND TRIMLINES}

Broad bottomed, U-shaped valley profiles visible in upper Boulder Valley, Clara Valley, and Suspicion Valley provide evidence for the former existence of a small valley glacier system (Figs. 2, 3a, 3b). An abrupt transition to an incised, V-shaped valley morphology occurs at $\sim 640 \mathrm{~m}$ a.s.l. in Boulder River, and is associated with a change from truncated to interlocking spurs. This point probably reflects the average down-valley extent of glacial erosion over several late-Pleistocene glacial cycles.

Cirques situated on the eastern flank of Lead Range represent the primary ice source for former glaciation in the Boulder River catchment (Fig. 3b). Cirque morphology in this region ranges from shallow, incipient hollows to classical, large over-deepened basins such as Lake Clara. Cirques in the upper reaches of Suspicion, Portia, and Kiwi Creeks are less developed and probably contributed relatively minor volumes of ice.

Laterally discontinuous trimlines separating ice-scoured bedrock from deeply-weathered regolith are widespread in granitic terrain within the Boulder River catchment. "Weathered" zones are restricted to regions above $\sim 1200 \mathrm{~m}$ a.s.l. and are characterized by grussified bedrock, significant accumulations of clay-rich regolith (up to $1 \mathrm{~m}$ ) and localized quartz pavement formation (Fig. 3c and 3d). "Fresh" zones lack these features, but often have crescentic gouges, crescentic fractures, or striae inscribed in bedrock surfaces. These directional indicators show that ice-flow in Boulder Valley was generally preconditioned by existing valley orientation, but was oblique to valley axes in upper Boulder Valley (Fig. 3e).

Landforms of glacial erosion are less prominent in upper Snow Valley. Cross-sectional valley morphology is U-shaped, but the transition to an incised V-shape is $\sim 300 \mathrm{~m}$ higher than in Boulder Valley. Small and poorly developed cirques occur on the eastern flank of Caesar Ridge and the incipient nature of these landforms probably reflects thinner, slower moving ice due to relatively low summit altitudes.

\section{MORAINE STRATIGRAPHY}

Moraines within the study area occupy two distinct landscape positions. Several are located well above the modern valley floor and indicate phases of valley glaciation, while the majority are situated adjacent to or immediately down-valley from former cirques (Fig. 2).

Lateral moraines on the eastern side of Suspicion Valley (Suspicion Creek lateral moraine) and Boulder Valley (Beak Creek lateral moraine), and beneath Lake Clara cirque (Lake Clara lateral moraine) represent the most extensive glacial limits preserved within Boulder River catchment (Fig. 2). Beak Creek lateral moraine and Lake Clara lateral moraine are concordant with trimlines separating deeply-weathered granite bedrock from glacially abraded bedrock, and collectively provide evidence for confluence between Boulder Valley and Lake Clara-sourced ice. The down-valley extent of this advance is uncertain as end moraines are not preserved. However, extrapolation beyond Beak Creek lateral moraine indicates ice probably advanced as far as the "U" to "V" transition in Boulder Valley.

Ten additional moraines located inside this ice-limit reflect a subsequent period of glacial stillstand(s). Hummocky moraine occupying the upper western portion of Boulder Valley (Fig. 3a) is the most striking example, but many smaller moraine loops are present on cirque lips.

Moraines in Snow River catchment are less abundant but indicate a similar pattern of glacial development. An end moraine, located $400 \mathrm{~m}$ up-valley from the valley $\mathrm{U}$ to $\mathrm{V}$ transition, provides evidence for a valley glacier $\sim 2.5 \mathrm{~km}$ long with a maximum ice thickness of $200 \mathrm{~m}$. A small moraine loop situated on the lip of Caesar Knob cirque indicates a subsequent phase of cirque occupation.

\section{LACUSTRINE SEDIMENTS}

Outcrop AC-1 is located on the southern bank of Ambrose Creek (Fig. 2), where a $3 \mathrm{~m}$ section of stratified sediments through an adjacent terrace remnant is exposed. This surface is $5-15 \mathrm{~m}$ wide and onlaps onto the northern (ice-distal) wall of Suspicion Creek lateral moraine (Fig. 2). Moderately to well-sorted silts and fine sands with distinct horizontal $\mathrm{mm}$ - to $\mathrm{cm}$-scale stratification compose much of the section, but are punctuated by lesser conglomeratic units. Seven texturally distinctive units are described in Figure 4.

Fine-grained stratified facies exposed in AC-1 are interpreted to have been deposited in a low-energy, lacustrine environment. Coarse-grained facies probably reflect short-lived incursions of fluvially transported material into a lacustrine environment. The possibility that these horizons represent a colluvial influence is precluded by abundant edge rounding on clasts.

Glacial development in upper Suspicion Creek, and subsequent damming of Ambrose Creek by a 300-m-long lateral moraine (Suspicion Creek lateral moraine), is considered the most likely mechanism for lake formation (Fig. 5). The dimensions of this paleolake are constrained by the location of AC-1, the intersection of Suspicion Creek lateral moraine with Ambrose Creek, and the surrounding topography. It was an elongate feature, $\sim 350 \mathrm{~m}$ long, $\sim 80 \mathrm{~m}$ wide, and $<40 \mathrm{~m}$ deep. 


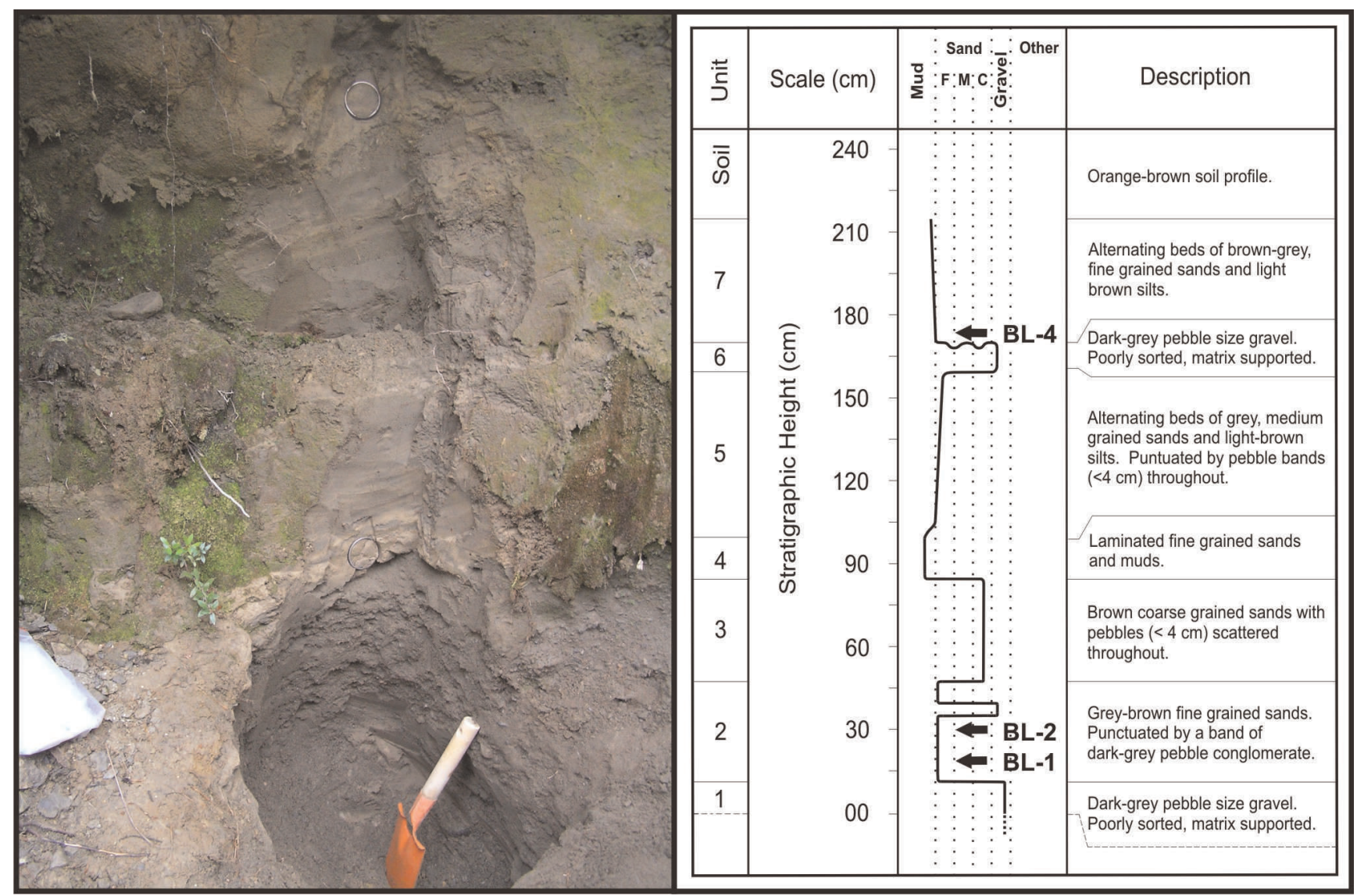

FIGURE 4. (Left) Photo showing stratification within AC-1. (Right) Grain-size variation within AC-1. BL-1, BL-2, and BL-4 refers to the position of luminescence samples.

\section{Timing}

\section{MIS 4 ADVANCE}

Luminescence samples (BL-1, BL-2, and BL-4) were retrieved from $20 \mathrm{~cm}, 30 \mathrm{~cm}$, and $170 \mathrm{~cm}$ above the base of AC-1, and yield ages of $64.9 \pm 10 \mathrm{ka}, 58.8 \pm 4.9 \mathrm{ka}$, and $54.6 \pm 5.6 \mathrm{ka}$, respectively. All samples suffered from the onset of saturation, as is evident in the growth curves shown in Figure 6. Using the program Analyst, the equivalent dose $\mathrm{D}_{\mathrm{e}}$ was obtained by fitting a saturating exponential curve to the data, and extrapolating back to the dose-axis. The uncertainty of this extrapolation is reflected in the relatively large $1 \sigma$-error estimates. None of the samples

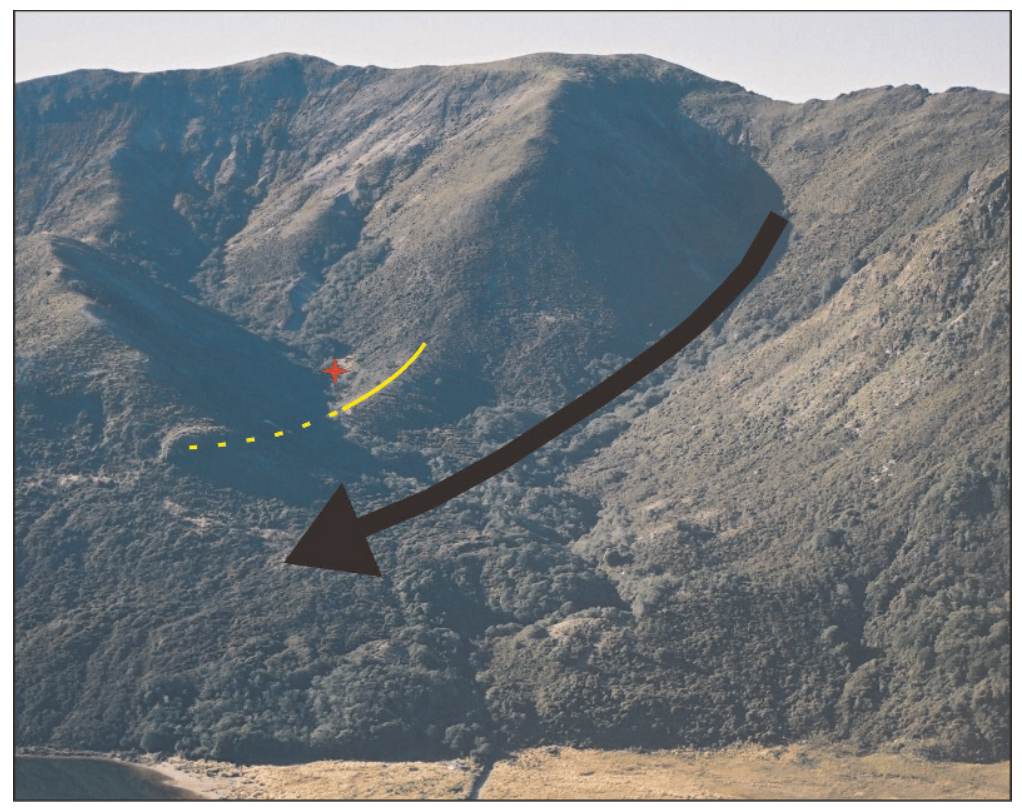

FIGURE 5. Glacial development in Suspicion Creek (black arrow) led to moraine damming of Ambrose Creek (white line), and subsequent lake formation. Luminescence ages retrieved from lake sediments exposed in $\mathrm{AC}-1$ (white star) constrain the timing of this advance. 

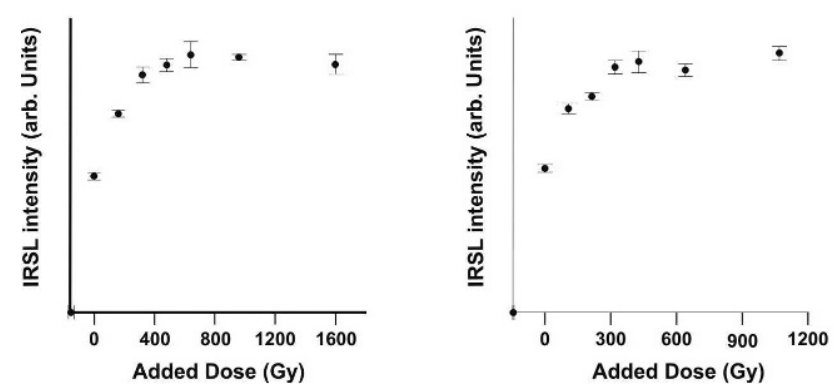

suffered from insufficient bleaching (shine-plateau test) or anomalous fading routine test of subsample after prolonged storage. Tables 3 and 4 summarize the OSL measurement data.

As all the samples are within error limits of each other, their appearance in stratigraphic order is only indicative. We conclude that sedimentation may have been rapid, which is consistent with the location of AC-1 within a high energy subalpine environment.

Sediments exposed in AC-1 reflect the presence of a morainedammed lake, and the basal luminescence age of $64.9 \pm 10 \mathrm{ka}$ must represent the minimum age of this moraine. A significant time lag between moraine construction and lake formation is considered unlikely because drainage in Ambrose Creek would become retarded immediately following dam formation. As such, the former Suspicion Creek glacier must have crossed Ambrose Creek a short time before $65 \mathrm{ka}$, during MIS 4 .

\section{MIS 2 MAXIMUM EXTENT PHASE}

Cosmogenic exposure sample BOU-3 (Fig. 3g) consisted of quartz veins retrieved from the upper surface of a granite boulder located at $1120 \mathrm{~m}$ a.s.l. on the eastern end of Beak Creek lateral moraine (Fig. 2). Deposition of this boulder by glacial processes is confirmed by its subrounded character and absence of granite bedrock in the surrounding region. Post-glacial reworking by gravity processes, and a disrupted period of cosmogenic nuclide

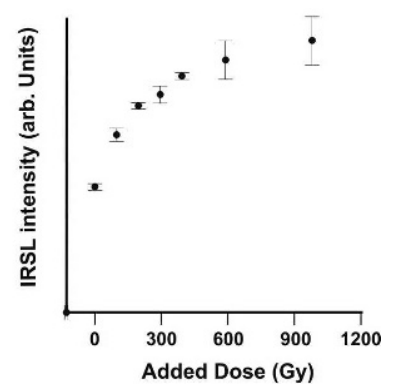

FIGURE 6. IRSL growth curve data of samples (A) BL-1, (B) BL-2, and (C) BL-4. The point in the origin of the graphs, representing the equivalent dose De, was calculated fitting a saturating-exponential function.

accumulation, is considered unlikely due to the size $(\sim 1 \mathrm{~m} \times 1 \mathrm{~m}$ $\times 1.5 \mathrm{~m}$ ) and position of this boulder near the moraine crest. Sample BOU-3 yielded a cosmogenic exposure age of $18.2 \pm$ $1.0 \mathrm{ka}$, indicating Beak Creek lateral moraine was deposited during an MIS 2 glacial advance. Landscape position, weathering rind thickness, and moraine morphology indicate Lake Clara lateral moraine was constructed during the same event (Table 5).

\section{MIS 2 RETRACTED PHASE}

Cosmogenic exposure sample BOU-2 (Fig. 3f) consisted of quartz veins retrieved from the upper surface of a very large granite boulder located at $1010 \mathrm{~m}$ a.s.l. on hummocky moraine in upper Boulder Valley (Fig. 2). Post-depositional reworking of this boulder is precluded by its size $(4 \mathrm{~m} \times 3 \mathrm{~m} \times 2 \mathrm{~m})$ and the flat character of the surrounding moraine. Sample BOU-2 yielded a cosmogenic exposure age of $17.8 \pm 0.9 \mathrm{ka}$, consistent with the exposure age for BOU-3. Mean weathering rind width on other granite-dominated moraines within the limits of MIS 2 glaciation range between $7.7 \mathrm{~mm}$ and $7.1 \mathrm{~mm}$, and are indistinguishable at the 95\% confidence level (Table 5). These features collectively represent a short-lived period of glacial re-advance or stillstand during rapid MIS 2 glacial retreat. They do not represent lateglacial advances documented in the central Southern Alps (Denton and Hendy, 1994; Ivy-Ochs et al., 1999).

TABLE 3

Radionuclide and water contents of luminescence samples.

\begin{tabular}{cccccc}
\hline \hline Sample name & Water content $\delta^{*}$ & $\mathrm{U}(\mu \mathrm{g} / \mathrm{g})$ from ${ }^{234} \mathrm{Th}$ & $\begin{array}{c}\mathrm{U}(\mu \mathrm{g} / \mathrm{g})^{\dagger} \text { from }{ }^{226} \mathrm{Ra}, \\
{ }^{214} \mathrm{~Pb},{ }^{214} \mathrm{Bi}\end{array}$ & $\mathrm{U}(\mu \mathrm{g} / \mathrm{g})$ from ${ }^{210} \mathrm{~Pb}$ & $\begin{array}{c}\mathrm{Th}(\mu \mathrm{g} / \mathrm{g})^{\dagger} \text { from }{ }^{208} \mathrm{Tl}, \\
{ }^{212} \mathrm{~Pb},{ }^{228} \mathrm{Ac}\end{array}$ \\
\hline BL-4 & 1.303 & $2.24 \pm 0.20$ & $2.14 \pm 0.13$ & $1.97 \pm 0.17$ & $9.78 \pm 0.11$ \\
BL-2 & 1.260 & $2.55 \pm 0.24$ & $2.12 \pm 0.15$ & $2.42 \pm 0.21$ & $9.34 \pm 0.12$ \\
BL-1 & 1.264 & $2.61 \pm 0.26$ & $1.87 \pm 0.16$ & $2.12 \pm 0.23$ & 9.03 \\
\hline
\end{tabular}

* Ratio of wet to dry sample weight. Errors assumed to be $50 \%$ of $(\delta-1)$.

${ }^{\dagger} \mathrm{U}$ and Th content is calculated from the error weighted mean of the isotope equivalent contents.

TABLE 4

Measured a-value and equivalent dose, dose rate, and luminescence age.

\begin{tabular}{lccccc}
\hline \hline Sample name & a-value & De $(\mathrm{Gy})$ & $\mathrm{dDc} / \mathrm{dt}(\mathrm{Gy} / \mathrm{ka})^{\dagger}$ & $\mathrm{dD} / \mathrm{dt}(\mathrm{Gy} / \mathrm{ka})$ \\
\hline BL-4 & $0.030 \pm 0.010^{*}$ & $129.3 \pm 6.9$ & $0.222 \pm 0.011$ & $2.37 \pm 0.21$ & $54.6 \pm 5.6$ \\
BL-2 & $0.030 \pm 0.010^{*}$ & $144.6 \pm 2.5$ & $0.183 \pm 0.009$ & $2.46 \pm 0.20$ & $58.8 \pm 4.9$ \\
BL-1 & $0.022 \pm 0.005$ & $152.0 \pm 19.5$ & $0.181 \pm 0.009$ & $2.34 \pm 0.20$ \\
\hline
\end{tabular}

* The a-value was estimated as the alpha-irradiated subsample was dose-saturated.

$\dagger$ Contribution of cosmic radiation to the total dose rate (Prescott and Hutton, 1994). 
TABLE 5

Altitude, mean weathering rind width, and crest width for moraines identified in the study area. Subdivision is based on moraine stratigraphy and confirmed by weathering rind data. Crest width on Snow and Clara end moraines is anomalously large, but probably reflects an extended period of cirque occupation rather than time since deglaciation. "?" refers to unsampled moraines, "NA" refers to moraines that were not sampled due to the absence of either granite or metasedimentary clasts.

\begin{tabular}{lccc}
\hline \hline \multicolumn{1}{c}{ Moraine } & Altitude $(\mathrm{m})$ & $\begin{array}{c}\text { Mean rind width } \\
\text { (granite) }(\mathrm{mm})\end{array}$ & $\begin{array}{c}\text { Mean rind width } \\
\text { (meta-sedimentary) }(\mathrm{mm})\end{array}$ \\
\hline Suspicion lateral moraine & $1150-1100$ & N/A & 0.9 \\
Beak Creek lateral moraine & $1170-1115$ & 8.6 & 2.6 \\
Lake Clara lateral moraine & $1220-1020$ & 9.1 & N/A \\
Boulder end moraine (a) & 1090 & 7.1 & N/A \\
Boulder end moraine (b) & 1095 & $?$ & N/A \\
Boulder end moraine (c) & 1050 & 7.4 & N/A \\
Snow end moraine & 1280 & N/A & ? \\
Lead end moraine & 1320 & 7.7 & N/A \\
Clara end moraine & 1350 & 7.3 & N/A \\
\hline
\end{tabular}

\section{Glacial Reconstruction}

Moraines and trimlines are used to reconstruct the extent, surface profile, and ELA of two MIS 2 glacial advances in Boulder and Snow Valley (Fig. 7). Survival of lacustrine sediments at Suspicion Creek indicates that glacial extent during MIS 4 was slightly greater than that during MIS 2 at Boulder Lake, but insufficient evidence is available to make a unique reconstruction of glacial extent during this event.

Error associated with paleo-ELA calculations may be grouped into two categories (Table 6). Methodological error is related to uncertainties inherent to each ELA reconstruction method. It is easily quantified for AAR and THAR solutions by applying error limits to an appropriate ratio, e.g., AAR $=0.65 \pm$ 0.05 . Reconstruction error reflects uncertainty in the position of former ice limits. It is difficult to quantify and is arbitrarily applied, acknowledging that uncertainty generally increases with older glaciations.

\section{MIS 2-MAXIMUM EXTENT PHASE}

Ice in the Boulder River catchment covered $8 \mathrm{~km}^{2}$ during the maximum MIS 2 advance, spread between two glaciers (Table 6). Boulder Glacier $\left(7 \mathrm{~km}^{2}\right)$ was $\sim 5 \mathrm{~km}$ long along and reached a maximum thickness of $200 \mathrm{~m}$ (Fig. 7). It had an unusual shape and ice flow pattern, which was preconditioned by a geologically controlled change in the orientation of Boulder Valley. Boulder Glacier had an AAR (0.65) derived ELA of $1162 \pm 30 \mathrm{~m}$ a.s.l. at this time. Error associated with this solution primarily reflects uncertainty in the position of the former ablation area $( \pm 25 \mathrm{~m})$, which is poorly defined. Methodological error inherent to the AAR technique is minimal $( \pm 5 \mathrm{~m})$ because the glacier sloped at a low angle in vicinity of the ELA (Fig. 8).

Lead Glacier $\left(\sim 1 \mathrm{~km}^{2}\right)$ was situated immediately north of Boulder Glacier (Fig. 7) but is analyzed independently as confluence between the two was restricted to their respective termini. It was $\sim 2 \mathrm{~km}$ long and characterized by thin ice, particularly in the accumulation area. Glacial landforms are weakly developed, and the reconstructed ice limits and ELA calculations are poorly constrained. A THAR of $0.45 \pm 0.05$ yields an ELA of $1047 \pm 84 \mathrm{~m}$ for Lead Glacier which includes a $40 \mathrm{~m}$ reconstruction error.

A glacier in Snow River catchment covered $3 \mathrm{~km}^{2}$ of ice during the probable MIS 2 advance. The glacier was $\sim 3 \mathrm{~km}$ long and reached a thickness of $170 \mathrm{~m}$ near its equilibrium-line. It had a "normal" area/altitude distribution (Fig. 8), and an AAR of 0.65 \pm 0.05 yields an ELA of $1178 \mathrm{~m} \pm 48 \mathrm{~m}$ a.s.l. (including $25 \mathrm{~m}$ of reconstruction error). A THAR $(0.45 \pm 0.05)$ derived solution of $1147 \pm 48$ m compares well.

\section{MIS 2-RETRACTED PHASE}

Six cirque glaciers, collectively covering $\sim 0.8 \mathrm{~km}^{2}$, were restricted to eastern aspects at this time (Fig. 7). THAR (0.45) derived ELA solutions vary from $1170 \mathrm{~m}$ a.s.l. to $1400 \mathrm{~m}$ a.s.l., and two groupings are apparent. Glaciers occupying the upper, true-left headwall of Boulder Valley had ELAs between $1170 \mathrm{~m}$ a.s.l. and $1200 \mathrm{~m}$ a.s.1. ELAs on Iron Hills Glacier, Clara Glacier, and Snow Glacier were higher at $1370 \mathrm{~m}$ a.s.1., $1390 \mathrm{~m}$ a.s.1., and $1320 \mathrm{~m}$ a.s.l., respectively. ELA variance is best explained by local interaction between topography and climate, rather than a regional precipitation gradient. Combined reconstruction and methodological error associated with these solutions is minimal and $\pm 30 \mathrm{~m}$ represents a maximum estimate (Table 6).

\section{Climatic Inferences}

\section{ELA DEPRESSION}

The difference between reconstructed and contemporary ELAs on glaciers provides insight into the magnitude of past climatic changes (Porter, 2001). Unfortunately the Tasman Mountains lack present-day glaciers, and the modern ELA is unknown. However, glaciers exist today in the Southern Alps and instrumental temperature data and an environmental lapse rate can be used to deduce a modern ELA and uncertainty (Colhoun, 1985). We use the mean annual freezing level as a proxy for the ELA (following Porter, 2001) and assume an environmental lapse rate of $6.5^{\circ} \mathrm{C} \mathrm{km}^{-1}$ (Barry, 1992). This yields a modern potential ELA of $2084 \mathrm{~m}$ a.s.l. for the Tasman Mountains.

An alternative approach utilizes known north-south snowline gradients to extrapolate end of summer snowline-derived ELA estimates from the Southern Alps to the Tasman Mountains (e.g., Shulmeister et al., 2005). Using published snowline (Chinn and Whitehouse, 1980) and precipitation (Griffiths and McSaveney, 1983) data, the modern ELA for a western site in the central Southern Alps, with a precipitation regime of $4500 \mathrm{~mm} \mathrm{yr}^{-1}$ is $\sim 1800 \mathrm{~m}$ a.s.l. Allowing for a northward ELA increase of $1.4 \mathrm{~m}$ $\mathrm{km}^{-1}$ (Lamont et al., 1999) produces a modern ELA of $2180 \mathrm{~m}$ a.s.l. in the study area.

Both solutions contain uncertainty, but $2135 \mathrm{~m}$ a.s.l. represents an average of the two estimates and is used from this point onwards. Equilibrium-lines were therefore $\sim 965 \mathrm{~m}$ lower than present during 

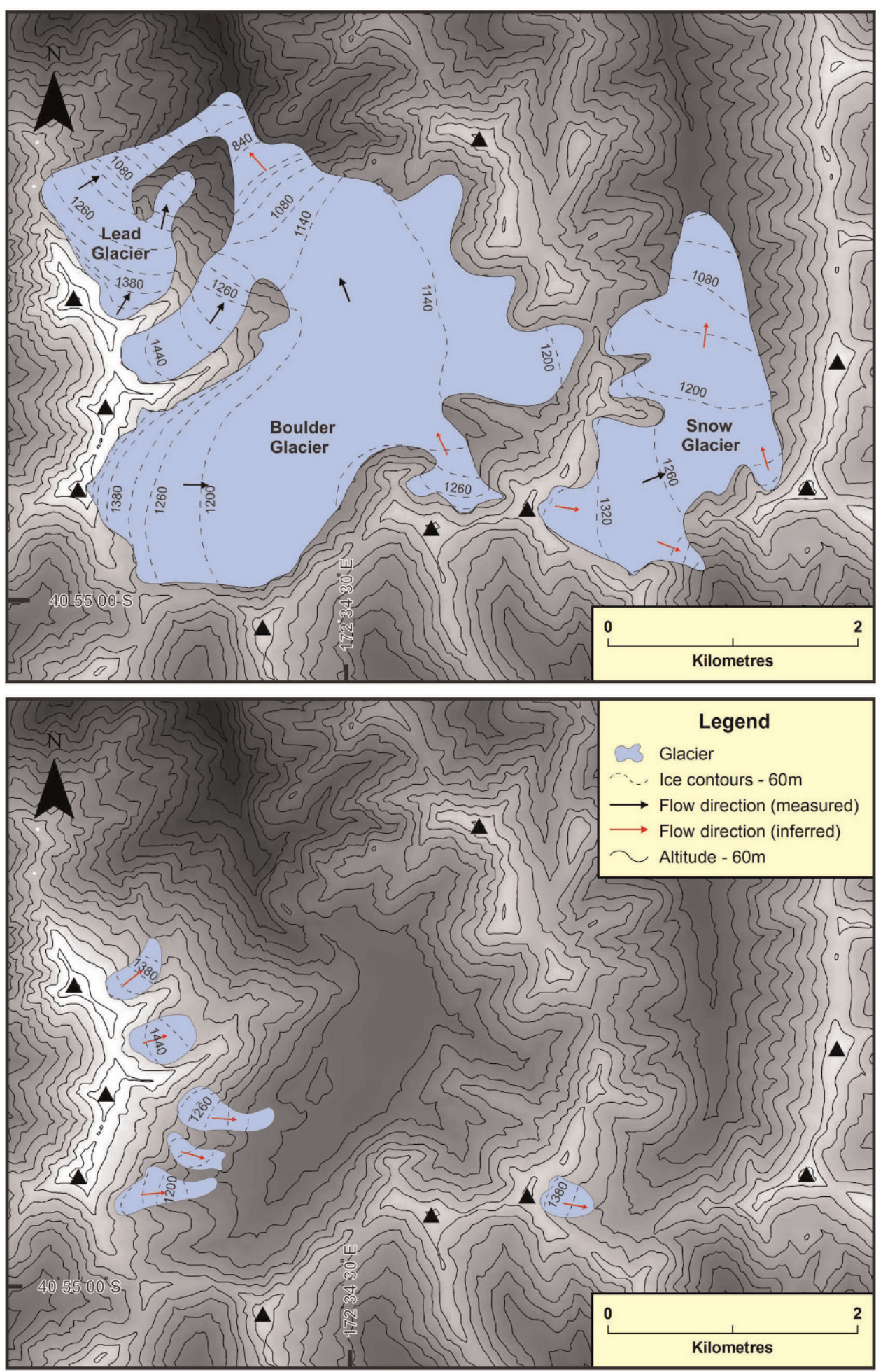

FIGURE 7. Glacial extent during the maximum extent phase (above) and retracted phase (below) of MIS 2 glaciation. Measured flow direction obtained from crescentic fracture/gouge and/or striae data, inferred flow direction estimated from reconstructed ice contours.
MIS 2 glaciation, and between 965 and $735 \mathrm{~m}$ lower during the subsequent retracted phase. Glaciation during the latter phase was extremely marginal. Headwall shading and snow drifting were probably more important than absolute temperature or precipitation levels, and thus climatic reconstruction is not attempted.

\section{TEMPERATURE AND PRECIPITATION RECONSTRUCTION}

ELA variation in the Tasman Mountains during the late Pleistocene was forced by a combination of ablation season temperature change and accumulation season precipitation change (Ohmura et al., 1992). Lapse rate considerations indicate thermal decline of about $6^{\circ} \mathrm{C}$ could drive the $965 \mathrm{~m}$ ELA depression. Less cooling is required if accompanied by precipitation increase. To place this uncertainty in context, modeling studies of the Franz Josef Glacier in New Zealand for the period from $13 \mathrm{ka}$ to the present day indicates that a $37 \%$ increase in precipitation is required to balance $1^{\circ} \mathrm{C}$ of warming (Anderson and Mackintosh, 2006). Using this finding as a constraint on the relative impact of precipitation variability, a cooling of $\sim 5-7^{\circ} \mathrm{C}$ may have occurred at Boulder Lake during both MIS 4 and 2, assuming a possible 
TABLE 6

ELA estimates and associated error for former glaciers in the study area. Anomalously low ELAs in upper Boulder Valley during the retracted phase of MIS 2 reflect glacial persistence due to solar shading.

\begin{tabular}{llcrr}
\hline \hline Age & \multicolumn{1}{c}{ Glacier } & $\begin{array}{c}\text { Area } \\
\left(\mathrm{km}^{2}\right)\end{array}$ & $\begin{array}{c}\text { ELA } \\
(\mathrm{m})\end{array}$ & $\begin{array}{c}\text { Error } \\
(\mathrm{m})^{*}\end{array}$ \\
\hline MIS 4 & Boulder Glacier & $<7.2 ?$ & $<1162$ & $?$ \\
Max extent & Boulder Glacier & 7.2 & 1162 & 30 \\
MIS 2 & Lead Glacier & 0.9 & 1178 & 48 \\
& Snow Glacier & 2.8 & 1047 & 84 \\
Retracted phase & Boulder Glacier (a) & 0.16 & 1197 & 28 \\
MIS 2 & Boulder Glacier (b) & 0.08 & 1170 & 25 \\
& Boulder Glacier (c) & 0.17 & 1184 & 31 \\
& Clara Glacier & 0.16 & 1394 & 21 \\
& Lead Glacier & 0.12 & 1368 & 27 \\
& Snow Glacier & 0.10 & 1323 & 22 \\
\hline
\end{tabular}

* Combined reconstruction and methodological error.

$\pm 30 \%$ change in precipitation. This is far in excess of likely variations, such as those simulated with a regional climate model for New Zealand (Drost et al., 2007).

\section{ATMOSPHERIC CIRCULATION AND SHADING}

Equilibrium-lines on cirque glaciers occupying southeastern aspects (upper Boulder Valley) were anomalously depressed during the retracted phase of MIS 2 glaciation (Table 6). This reflects the role of solar shading and snow drift in determining where late-stage glaciation could persist.

Accumulation areas of Boulder and Snow Glaciers during MIS 2 glaciation were inclined eastward, subparallel to major valley axes (Fig. 7). Cirque glaciers during the subsequent retracted phase were restricted to eastern-facing aspects, rather than valley heads (Fig. 7). Both patterns of glacial development reflect preferential lee-side snow accumulation during a period of prevailing westerly airflow. This finding is consistent with a regional eastward ascent of glacier equilibrium-lines from $\sim 1170 \mathrm{~m}$ a.s.l. in the Tasman Mountains (this study) to $\sim 1790 \mathrm{~m}$ a.s.l. in the Inland Kaikoura Range (Bacon et al., 2001). It is also supported by dust, pollen, and theoretical data, which indicate that westerly airflow was important in New Zealand during the LGM (Shulmeister et al., 2004), as it is today.

\section{Discussion}

Geomorphic, cosmogenic, luminescence, and relative age data presented in this study provide evidence for three episodes of glacial expansion in the Boulder Lake region. Ice extent was greatest during the earliest of these advances, which began prior to $\sim 65 \mathrm{ka}$, during MIS 4 (Table 7). A second similar or slightly less extensive phase of valley glaciation culminated at $\sim 18 \mathrm{ka}$, representing the LGM event documented elsewhere in New Zealand (Suggate, 1990; Shulmeister et al., 2005; Schaefer et al., 2006). Rapid deglaciation was interrupted by a period of cirque occupation.

\section{MIS 4 GLACIATION}

Data from the Tasman Mountains support the emerging view that mountain glaciers were more extensive during MIS 4 than MIS 2. Since this idea was originally canvassed by Gillespie and Molnar (1995), more extensive glaciations during the earlier part of the LGC have been documented within New Zealand in Fiordland (Williams, 1996) and Westland (Preusser et al., 2005; Sutherland et al., 2007). Similar findings have emerged in southeastern Australia including Tasmania (Barrows et al., 2002; Mackintosh et al., 2006), the Swiss Alps (Preusser and Schlüchter, 2004) and the North American cordillera (Phillips et al., 1996). These findings contrast with marine $\delta^{18} \mathrm{O}$-derived records of global ice volume, which indicate northern hemisphere ice sheets reached their maximum at $\sim 20$ ka during the LGM (Bard et al., 1990). This apparent mismatch between ice sheet (volume) and mountain glacier extent leads us to postulate that the more extensive ice limits during MIS4 documented in this study might reflect an underappreciated global pattern, with an underlying climatic cause (or otherwise).

There are several possible explanations for why MIS 4 glacial advances could have been more extensive. It could be that MIS 4 was actually colder than MIS 2 in temperate mountain belts, or that it lasted longer, providing more time for mountain glaciers to equilibrate with climate. Cooling coupled with elevated precipitation might offer an explanation, but it seems insufficient given the local nature of precipitation variability.

Several other possibilities exist. Sutherland et al. (2007) and Vandergoes et al. (2005) have suggested that southern hemisphere insolation was an important driver of glacier extent and climate during the LGC. However, this seems unlikely in the case of MIS4 if mountain glaciers were simultaneously more extensive in both hemispheres because variations in summer insolation intensity are antiphased between the northern and southern hemispheres. Alternatively, the limited glacial extent during MIS 2 could be related to the tendency of mountain glaciers to erode vertically, lowering themselves out of equilibrium with local climatic conditions (Kaplan et al., 2008) and therefore reducing their extent though time. Further improvement in mountain glacier chronologies and other proxy evidence are required to properly address these issues.

\section{MIS 2 GLACIATION}

Temperature depression in southern mid/high latitudes during the LGC is traditionally thought to have culminated
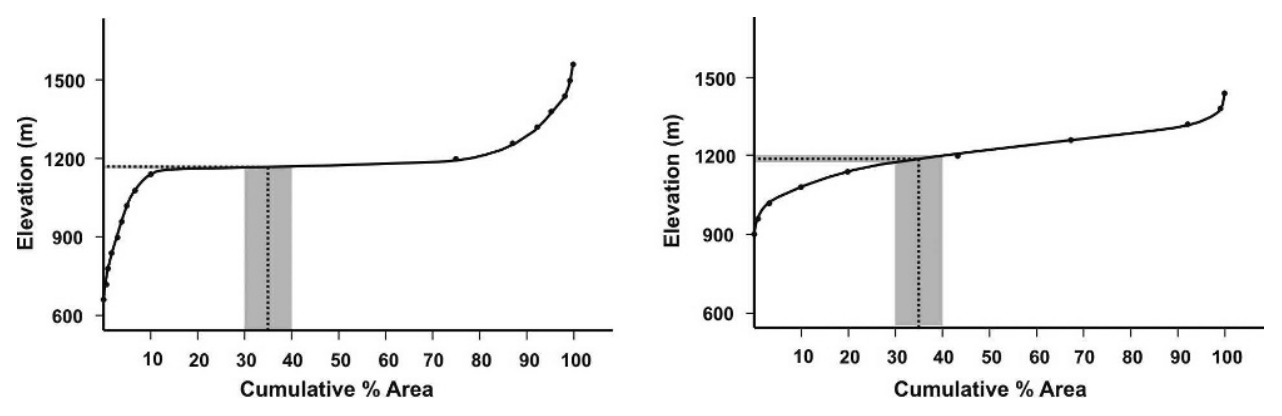

FIGURE 8. Area-altitude curves for Boulder Valley glacier (left) and Snow Valley glacier (right) during the maximum extent phase of MIS 2 glaciation. A conventional AAR (0.65 \pm .05$)$ yields ELAs of $1162 \pm 5 \mathrm{~m}$ a.s.l. and $1178 \pm$ $23 \mathrm{~m}$ a.s.l., respectively. 
TABLE 7

Correlation of glacial expansions identified in the study area with several well-dated New Zealand glacial sequences. Events in boldface type are considered the largest in their catchment.

\begin{tabular}{|c|c|c|c|c|c|c|c|}
\hline MIS & Glaciation & $\begin{array}{c}\text { Fiordland } \\
\text { (Williams, 1996) }\end{array}$ & $\begin{array}{l}\text { North Westland } \\
\text { (Suggate, 1990) }\end{array}$ & $\begin{array}{l}\text { South Westland } \\
\text { (Almond et al., 2001) }\end{array}$ & $\begin{array}{l}\text { Cobb Valley } \\
\text { (Shulmeister } \\
\text { et al., 2005) }\end{array}$ & $\begin{array}{l}\text { Boulder Valley } \\
\text { (this study) }\end{array}$ & $\begin{array}{c}\text { Ages } \\
(\mathrm{ka})\end{array}$ \\
\hline \multicolumn{8}{|l|}{1} \\
\hline \multirow[t]{4}{*}{2} & Otira & Aurora-1 & & Waiho Loop & & & $11-14$ \\
\hline & & Aurora-2 & Moana & M6 & & $\leftarrow$ & $14-17$ \\
\hline & & Aurora-3 & Larrikans-2 & M5 & Cobb & $\leftarrow$ & $18-24$ \\
\hline & & & Larrikans-1 & M4b & & & $28-34$ \\
\hline 3 & & Aurora-4 & & & & & $40-41$ \\
\hline \multirow[t]{2}{*}{4} & & Aurora-5 & & M4a & & & $46-50$ \\
\hline & & Aurora-6 & Loopline & M3, M2 & & $\leftarrow$ & $67-70$ \\
\hline 5 & & & & & & & \\
\hline
\end{tabular}

during MIS 2 (Nelson et al., 1994; Petit et al., 1999; Barrows and Juggins, 2005). The magnitude of cooling that New Zealand experienced during this period has been controversial, with terrestrial (fossil beetle and pollen) data indicting 0 to $-7^{\circ} \mathrm{C}$ (Marra et al., 2006; Shulmeister et al., 2001) and proximal marine evidence indicating cooling of $4-5^{\circ} \mathrm{C}$ in most areas and $7-8^{\circ} \mathrm{C}$ on the Campbell Plateau to the east of New Zealand (Barrows and Juggins, 2005). Glacier equilibrium-lines in the Boulder Lake region were $\sim 960 \mathrm{~m}$ lower than present during MIS 2. This figure compares well to "averaged" mid-latitude LGM ELA depression of $900 \pm 50 \mathrm{~m}$ (Porter et al., 1983), but is somewhat greater than speleothem growth trends indicating a tree-line lowering of 600 $700 \mathrm{~m}$ in the Tasman Mountains during MIS 2 (Hellstrom et al., 1998). Similar ELA depressions to ours have been documented in the central and northeastern Southern Alps (Porter, 1975; Bacon et al., 2001). Our estimate of $\sim 5-7^{\circ} \mathrm{C}$ cooling is within error of previous work but is suggestive of a larger cooling than some proxy evidence.

\section{CONCLUSIONS}

Luminescence dating of ice-marginal sediments and ${ }^{10} \mathrm{Be}$ and ${ }^{26} \mathrm{Al}$ exposure ages from moraine boulders at Boulder Lake, New Zealand, indicate that two ice advances occurred during the Last Glacial Cycle, one at $\sim 65 \mathrm{ka}$ during Marine Isotope Stage 4 (MIS 4 ) and another at $\sim 18 \mathrm{ka}$ (MIS 2). The MIS 4 advance was slightly more extensive.

An equilibrium-line lowering of $960 \mathrm{~m}$ is required to cause ice advance to both the MIS 4 and MIS 2 glacier extents. This relatively low-elevation $(\sim 1600 \mathrm{~m})$ site requires a substantial cooling of $>5^{\circ} \mathrm{C}$ to cause ice advance to these positions, even if local precipitation increased by more than $30 \%$. If precipitation decreased as one model suggests (Drost et al., 2007), cooling during MIS 2 may have been as great as $7^{\circ} \mathrm{C}$. MIS 4 precipitation levels are more poorly understood and thus our temperature reconstruction for this period has greater uncertainty.

Our findings mirror many new studies that mountain glaciers in both hemispheres were more advanced during MIS 4 ( $\sim 65 \mathrm{ka})$ than MIS 2.

\section{Acknowledgments}

We would like to thank Mrs. N. Wang for her careful work in preparing the OSL samples. We would also like to thank Jamie Shulmeister for suggesting Boulder Lake as a study site. The input of two anonymous reviewers and Suzanne Anderson led to substantial improvements in the manuscript.

\section{References Cited}

Adamiec, G., and Aitken, M. J., 1998: Dose-rate conversion factors: update. Ancient TL, 16: 37-50.

Alloway, B. V., Almond, P. C., Augustinus, P. C., Barrell, D. J. A., Bertler, N. A. N., Carter, L., Litchfield, N. J., Lowe, D. J., McGlone, M. S., Newnham, R. M., Shulmeister, J., Vandergoes, M. J., Williams, P. W., and NZ-INTIMATE Members, 2007: Towards a climate event stratigraphy for New Zealand over the past 30,000 years. Journal of Quaternary Science, 22(1): 9-35.

Almond, P. C., Moar, N. T., and Lian, O. B., 2001: Reinterpretation of the glacial chronology of South Westland, New Zealand. New Zealand Journal of Geology and Geophysics, 44: $1-15$.

Anderson, B., and Mackintosh, A., 2006: Temperature change is the major driver of late glacial and Holocene glacier fluctuations in New Zealand. Geology, 34(2): 121-124.

Bacon, S. N., Chinn, T. J., Van Dissen, R. J., Tillinghast, S. F., Goldstein, H. L., and Burke, R. M., 2001: Paleo-equilibrium line altitude estimates from late Quaternary glacial features in the Inland Kaikoura Range, South Island, New Zealand. New Zealand Journal of Geology and Geophysics, 44: 55-67.

Ballantyne, C. K., 2002: Paraglacial geomorphology. Quaternary Science Reviews, 21: 1935-2017.

Bard, E., Hamelin, B., and Fairbanks, R. G., 1990: U/Th ages obtained by mass spectrometry in corals from Barbados: sea level during the past 130,000 years. Nature, 346: 456-458.

Barrows, T. T., and Juggins, S., 2005: Sea surface temperatures around the Australian margin and Indian Ocean during the Last Glacial Maximum. Quaternary Science Reviews, 24: 1017-1047.

Barrows, T. T., Stone, J. O., Fifield, K. L., and Cresswell, R. G., 2002: The timing of the Last Glacial Maximum in Australia. Quaternary Science Reviews, 21: 159-173.

Barry, R. G., 1992: Mountain Weather and Climate. London: Routledge, $402 \mathrm{pp}$.

Child, D., Elliott, G., Misfud, C., Smith, A. M., and Fink, D., 2000: Sample processing for earth science studies at ANTARES. Nuclear Instruments and Methods, B172: 856-860.

Chinn, T. J., and Whitehouse, I. E., 1980: Glacier and snowline variations in the Southern Alps, New Zealand. IAHS-AISH Publication, 126: 219-228.

Colhoun, E. A., 1985: Glaciations of the West Coast Range, Tasmania. Quaternary Research, 24: 39-59.

Colman, S. M., and Pierce, K. L., 1981: Weathering rinds on andesitic and basaltic stones as Quaternary age indicators, 
Western United States. U.S. Geological Survey Professional Paper, 1210.

Colman, S. M., and Pierce, K. L., 1986: Effect of height and orientation (microclimate) on geomorphic degradation rates and processes, late-glacial terrace scarps in central Idaho. Geological Society of America Bulletin, 97: 869-885.

Denton, G. H., and Hendy, C. H., 1994: Younger Dryas age advance of Franz Josef Glacier in the Southern Alps of New Zealand. Science, 264: 1434-1437.

Dobson, A. D., 1872: On the traces of ancient glaciers in Nelson province. Transactions of the New Zealand Institute, 4: 336-341.

Drost, F., Renwick, J., Bhaskaran, B., Oliver, H., and McGregor, J., 2007: A simulation of New Zealand's climate during the Last Glacial Maximum. Quaternary Science Reviews, 26: $2505-2525$.

Dunai, T. J., 2000: Scaling factors for production rates of in situ produced cosmogenic nuclides: a critical reevaluation. Earth and Planetary Science Letters, 176: 157-169.

Dunai, T. J., 2001: Influence of secular variation of the geomagnetic field on production rates of in situ produced cosmogenic nuclides. Earth and Planetary Science Letters, 193: $197-212$.

Fink, D., and Smith, A., 2007: An inter-comparison of ${ }^{10} \mathrm{Be}$ and ${ }^{26} \mathrm{Al}$ AMS reference standards and the ${ }^{10} \mathrm{Be}$ half-life. Nuclear Instruments and Methods, B259: 600-609.

Fink, D., Hotchkis, M. A. C., Hua, Q., Jacobsen, G. E., Smith, A. M., Zoppi, U., Child, D., Mifsud, C., van der Gaast, H. A., Williams, A. A., and Williams, M., 2004: The ANTARES AMS Facility at ANSTO. Nuclear Instruments and Methods, B223224: 109-115.

Gillespie, A., and Molnar, P., 1995: Asynchronous maximum advances of mountain and continental glaciers. Reviews of Geophysics, 33: 311-364.

Griffiths, G. A., and McSaveney, M. J., 1983: Distribution of mean annual precipitation across some steepland regions of New Zealand. New Zealand Journal of Science, 26: 197-209.

Hallet, B., and Putkonen, J., 1994: Surface dating of dynamic landforms: young boulders on aging moraines. Science, 265: 937-940.

Hellstrom, J., McCulloch, M., and Stone, J., 1998: A detailed 31,000 year record of climate and vegetation change, from isotope geochemistry of two New Zealand speleothems. Quaternary Research, 50: 167-178.

Henderson, J., 1923: Department report: notes to accompany a geological sketch map of the Mount Arthur region. New Zealand Journal of Science and Technology, 6: 174-190.

Ivy-Ochs, S., Schlüchter, C., Kubik, P. W., and Denton, G. H., 1999: Moraine exposure dates imply synchronous Younger Dryas glacial advances in the European Alps and in the Southern Alps of New Zealand. Geografiska Annaler, 81A: 313-323.

Kaplan, M., Hein, A., Hubbard, A., and Lax, S., 2008: Can glacial erosion limit the extent of glaciation? Geomorphology. in press.

Lamont, G. N., Chinn, T. J., and Fitzharris, B. B., 1999: Slopes of glacier ELAs in the Southern Alps of New Zealand in relation to atmospheric circulation patterns. Global and Planetary Change, 22: 209-219.

Lang, A., and Wagner, G. A., 1997: Infrared stimulated luminescence dating of Holocene colluvial sediments using the $410 \mathrm{~nm}$ emission. Quaternary Geochronology (Quaternary Science Reviews), 16: 393-396.

Leonard, E. M., 1984: Late Pleistocene equilibrium-line altitudes and modern snow accumulation patterns, San Juan Mountains, Colorado, U.S.A. Arctic and Alpine Research, 16: 65-76.

Mackintosh, A. N., Barrows, T. T., Colhoun, E. A., and Fifield, L. K., 2006: Exposure dating and glacial reconstruction at Mt. Field, Tasmania, Australia, identifies MIS 3 and MIS 2 glacial advances and climatic variability. Journal of Quaternary Science, 21: $363-376$.
Marra, M. J., Shulmeister, J., and Smith, E. G. C., 2006: Reconstructing temperature during the Last Glacial Maximum from Lyndon Stream, South Island, New Zealand using beetle fossils and maximum likelihood envelopes. Quaternary Science Reviews, 25: 1841-1850.

McGlone, M. S., Salinger, M. J., and Moar, N. T., 1993: Paleovegetation studies of New Zealand's climate since the Last Glacial Maximum. In Wright, J. E. Jr, Kutzbach, J. E., Webb, T. III, Ruddiman, W. F., Street-Perrott, F. A., and Bartlein, P. J. (eds.), Global climates since the Last Glacial Maximum. London: University of Minnesota Press, 294-317.

Meierding, T. C., 1982: Late Pleistocene glacial equilibrium-line altitudes in the Colorado Front Range: a comparison of methods. Quaternary Research, 18: 289-310.

Middleton, R., Brown, L., Dezfouly-Arjomandy, B., and Klein, J., 1993: On ${ }^{10} \mathrm{Be}$ standards and the half-life of ${ }^{10} \mathrm{Be}$. Nuclear Instruments and Methods, B82: 399-403.

Nelson, C. S., Hendy, C. H., and Cuthbertson, A. M., 1994: Oxygen isotope evidence for climatic contrasts between Tasman Sea and Southwest Pacific Ocean during the late Quaternary. In Van Der Lingen, G. J., Swanson, K. M., and Muir, R. J. (eds.), Evolution of the Tasman Sea Basin. Rotterdam: A.A. Balkema, 181-195.

and New Zealand Meteorological Service, 1978: Rainfall normal for New Zealand, 1941-1970. New Zealand Meteorological Survey Miscellaneous Publication, 145.

Nishiizumi, K., Imamura, M., Caffee, M., Southon, J., Finkel, R., and McAninch, J., 2007: Absolute calibration of ${ }^{10}$ Be AMS standards. Nuclear Instruments and Methods, B258: 403-413.

Ohmura, A., Kasser, P., and Funk, M., 1992: Climate at the equilibrium line of glaciers. Journal of Glaciology, 38: 397-411.

Petit, J. R., Jouzel, J., Raynaud, D., Barkov, N. I., Barnola, J. M., Basile, I., Bender, M., Chappellaz, J., Davis, M., Delaygue, G., Delmotte, M., Kotlyakov, V. M., Legrand, M., Lipenkov, V. Y., Lorius, C., Pepin, L., Ritz, C., Saltzman, E., and Stievenard, M., 1999: Climate and atmospheric history of the past 420,000 years from the Vostok ice core, Antarctica. Nature, 399: 429-435.

Phillips, F. M., Zreda, M. G., Benson, L. V., Plummer, M. A., Elmore, D., and Sharma, P., 1996: Chronology for fluctuations in late Pleistocene Sierra Nevada glaciers and lakes. Science, 274: 749-751.

Porter, S. C., 1975: Equilibrium-line altitudes of late Quaternary glaciers in the Southern Alps, New Zealand. Quaternary Research, 5: 27-47.

Porter, S. C., 2001: Snowline depression in the tropics during the last glaciation. Quaternary Science Reviews, 20: 1067-1091.

Porter, S. C., Pierce, K. L., and Hamilton, T. D., 1983: Late Wisconsin mountain glaciation in the western United States. In Porter, S. C. (ed.), Late Quaternary environments of the United States: the late Pleistocene. Minneapolis: University of Minnesota Press, 71-111.

Prescott, J. R., and Hutton, J. T., 1994: Cosmic ray contributions to dose rates for luminescence and ESR dating: large depths and long-term variations. Radiation Measurements, 23: 497-500.

Preusser, F., and Schlüchter, Ch., 2004: Dates from an important early Late Pleistocene ice advance in the Aare Valley, Switzerland. Eclogae Geologicae Helvetiae, 97: 245-253.

Preusser, F., Anderson, B. G., Denton, G. H., and Schlüchter, C., 2005: Luminescence chronology of late-Pleistocene glacial deposits in North Westland, New Zealand. Quaternary Science Reviews, 24: 2207-2227.

Putkonen, J., and Swanson, T., 2003: Accuracy of cosmogenic ages for moraines. Quaternary Research, 59: 255-261.

Salinger, M. J., 1983: New Zealand climate; the last 5 million years. In Vogel, J. C. (ed.), Late Cainozoic palaeoclimates of the Southern Hemisphere. Rotterdam: A.A. Balkema, 131-150.

Schaefer, J., Denton, G., Barrell, D., Ivy Ochs, S., Kubik, P., Anderson, B., Phillips, F., Lowell, T., and Schlüchter, C., 2006: 
Near-synchronous interhemispheric termination of the last glacial maximum in mid latitudes. Science, 312: 1510-1513.

Shulmeister, J., Okuda, M., Carter, J. A., Harper, M., Dickinson, W., Augustinus, P., Hiejnis, J., Shane, P., and Lian, O. B., 2001: A long late-Quaternary record from Lake Poukawa, Hawke's Bay, New Zealand. Palaeogeography, Palaeoclimatology, Palaeoecology, 176: 81-107.

Shulmeister, J., Goodwin, I., Renwick, J., Harle, K., Armand, L., McGlone, M. S., Cook, E., Dodson, J., Hesse, P. P., Mayewski, P., and Curran, M., 2004: The southern hemisphere westerlies in the Australasian sector over the last glacial cycle: a synthesis. Quaternary International, 118-119: 23-53.

Shulmeister, J., Fink, D., and Augustinus, P. C., 2005: A cosmogenic nuclide chronology of the last glacial transition in North-West Nelson, New Zealand-New insights in southern hemisphere climate forcing during the last deglaciation. Earth and Planetary Science Letters, 233: 455-466.

Smith, J. A., Seltzer, G. O., Farber, D. L., Rodbell, D. T., and Finkel, R. C., 2005: Early local last glacial maximum in the tropical Andes. Science, 308: 678-681.

Stone, J. O., 2000: Air pressure and cosmogenic isotope production. Journal of Geophysical Research-Solid Earth, 105: 23,753-23,759.

Stone, J. O., Ballantyne, C. K., and Fifield, C. K., 1998: Exposure dating and validation of periglacial weathering limits, NW Scotland. Geology, 26: 587-590.

Suggate, R. P., 1990: Late Pliocene and Quaternary glaciations of New Zealand. Quaternary Science Reviews, 9: 175-199.

Sutherland, R., Kim, K., Zondervan, A., and McSaveney, M., 2007: Orbital forcing of mid-latitude southern hemisphere glaciation since $100 \mathrm{ka}$ inferred from cosmogenic nuclide ages of moraine boulders from the Cascade Plateau, southwest New Zealand. GSA Bulletin, 119: 443-451.

Vandergoes, M. J., Newnham, R. M., Preusser, F., Hendy, C. H., Lowell, T. V., Fitzsimons, S. J., Hogg, A. G., Kasper, H. U., and Schlüchter, C., 2005: Regional insolation forcing of late Quaternary climate change in the southern hemisphere. Nature, 436: 242-245.

Vogt, S., Wang, M. S., Li, R., and Lipschutz, M., 1994: Chemistry operations at Purdue's accelerator mass spectrometry facility. Nuclear Instruments and Methods, B92: 153-157.

Wellman, H. W., 1940: Geological and geophysical surveys, Cobb Valley, Nelson, New Zealand. New Zealand Journal of Science and Technology, 22: 52-61.

Williams, P. W., 1996: A $230 \mathrm{ka}$ record of glacial and interglacial events from Aurora Cave, Fiordland, New Zealand. New Zealand Journal of Geology and Geophysics, 39: 225241.

Williams, P. W., King, D. N. T., Zhao, J. X., and Collerson, K. D., 2005: Late Pleistocene to Holocene composite speleothem ${ }^{18} \mathrm{O}$ and ${ }^{13} \mathrm{C}$ chronologies from South Island, New Zealand; did a global Younger Dryas really exist? Earth and Planetary Science Letters, 230: 301-317.

Woo, M., and Fitzharris, B. B., 1992: Reconstruction of mass balance variations for Franz Josef Glacier, New Zealand, 19131989. Arctic and Alpine Research, 24: 281-290. 